\title{
Path Analysis and Correlation of Influential Socioeconomic Factors in the Production of Sugarcane
}

\author{
Jean Marc Nacife (Corresponding author), Frederico Antônio Loureiro Soares, Gustavo \\ Castoldi \\ Postgraduation Program in agricultural Sciences, Goiano Federal Institute \\ Av. Sul Goiana - Km 01, Rio Verde, Goiás, Brasil \\ Tel: 55-64-99963-4589Ｅ-mail: jean.nacife@ifgoiano.edu.br
}

Received: August 16, 2019

doi:10.5296/jas.v7i4.15389
Accepted: Sep. 2, 2019 Published: Sep. 3, 2019

URL: https://doi.org/10.5296/jas.v7i4.15389

\begin{abstract}
The analysis of the economic viability of agriculture and sugar cane is necessary to understand the techniques of measuring the financial return on the activities of rural establishments. The authors aimed to examine the direct and indirect associations of socioeconomic factors on the benefit/cost index in sugarcane activity and their significant correlations. The methodological approach of research was quantitative, applying statistical techniques of inferential and multivariate analysis (path analysis) under statistical significance $(\mathrm{P}<0.05)$. A model of path diagram was developed that presented a structural adjustment of quality, obtaining relevant $\mathrm{R}^{2}(0.74)$. The analysis showed that the characteristics of the successors of the farms impact on the economic factors of the productive system of the sugar cane. There was a total association between the successor's vocation and the benefit/cost index, presenting a substantial path coefficient (-0.90), in which the direct and indirect effect (51\% and $49 \%$ ) was inversely proportional and had a significant impact $(\mathrm{P}<0.05)$. A total association between the successor's practical ability and the benefit/cost index was obtained, which presented a strong and directly proportional path coefficient (0.70). In the dynamics of the socioeconomic factors of the sugarcane productive system, the influence of social variables on the economic result is expressive, and the indirect effects impact in a manner similar to the direct ones, as evidenced by the analysis of the benefit/cost, implying the adoption of actions that prepare the successors for agricultural management and for the management of agribusiness.
\end{abstract}

Keywords: agricultural economics, benefit/cost index, sugarcane expansion, sugarcane socioeconomic indexes 


\section{Introduction}

In Brazil, only the State of Goiás and the Brazilian Federal District in the period from 2003 to 2013 had the area planted with sugarcane expanded six times. However, little is known about the factors that involve the expansion of sugarcane borders, especially in the state of Goiás. To understand the mechanisms of influence in the environmental, economic and social spheres is gaining increasing importance. The management of the future of agricultural propagation, and especially of sugarcane, is fundamental to understand the socioeconomic factors that shape its growth in Brazil and in the municipalities of Goiás (Spera et al., 2017).

In order to analyze the economic viability of agriculture and sugarcane, it is necessary for the farmer to understand the techniques of measuring financial returns (Barnes et al., 2015), referring to the practice of planning in agriculture as an instrument (Santos et al., 2016). In the case of sugarcane plantations, the sugarcane crop is one of the most traditional crops in Brazil (Santos et al., 2016). In this context, the analysis of the benefit/cost indicator has been consolidated as an important tool at the global level in order to determine the economic efficiency of the management actions (FAO, 2016).

The benefit/cost analysis has been applied in various fields of science, and used for economic evaluation in the United States, Great Britain, Switzerland and in several developing countries (Špačková and Straub, 2015). Thus, a better understanding of the socioeconomic factors of the sugarcane productive system, supported by statistical methods, can enable the farmer to use a wealth of tools to support both the planning process and the decision. Profitability can be achieved with very different attributes and with equally distinct social outcomes (Dubb, 2017).

The authors specifically propose the application of Structural Equation Modeling (SEM) and the use of statistical procedures to determine the direct and indirect effects to estimate the association of predictor variables in relation to the benefit/cost variable (Bellino et al., 2015; Qaswar et. al., 2019). In this sense, the objective is to examine the direct and indirect causal associations of socioeconomic factors on the benefit/cost index of the sugarcane activity related to rural establishments in the municipality of Quirinópolis, evaluating them and characterizing the heterogeneity between the leasing and supplier profiles of the farms hired by the local agribusiness companies.

\section{Material and Methods}

Field research was conducted in the period from June 2018 to February 2019, with the owners. The studied rural settlements are located in the rural microregions of the municipality of Quirinópolis, geographically positioned by the coordinates: 18²6'52 "south latitude and $50^{\circ} 27^{\prime} 07^{\prime \prime}$ west longitude, located in the southwest of Goiás, and in the South Goiano mesoregion (IBGE, 2018b). The population surveyed comprised 67 agricultural establishments that make up the sugar cane production system (IBGE, 2018a). The sample calculation adopted the $95 \%$ confidence level and 5\% margin of error, resulting in a sample with 58 establishments (Santos, 2016). In the data collection, printed questionnaires were used for interviews, covering seventeen rural microregions. 


\subsection{Indicators, Measures and Variables}

The elaboration of the structural equation modeling and trail analysis were applied in the socioeconomic variables of the agricultural establishments, as described:

a) Succession index - vocation (ISVO): this indicator affects the perception of the level of vocation of the successors to assume the rural activities.

b) Succession index - practical ability (ISPS): evaluates the perception of the ability of successors to perform the technical and management activities of rural establishments.

c) Benefit / cost index (IBCcane): composed of the ratio of total remuneration to total cost.

d) Total operational cost of sugarcane in (ICcane): it covers inputs, labor, machinery, administrative expenses, labor costs and depreciation. ICcane was calculated in relation to the 2017/2018 sugarcane harvest in the establishments. The remuneration comes from the production of sugarcane (Rcane), calculated based on the ton of sugarcane produced and converted by the quotation of Total Recoverable Sugar (ATR), by CONSECANA (2018) of July 10, 2018, and its currency conversion (real to U.S. dollar) was carried out on the same date based on the quotation of the Central Bank of Brazil. For the purposes of this study, the remunerations of agricultural establishments are prorated by the productive area in order to obtain the value of the compensation per hectare (US\$/ha) and to provide a calculation of the indicators.

e) Size of the agricultural establishment (SizeEstablis): measured by the size of the rural property, an important variable for cost analysis and potential remuneration. In this study, establishments were identified in the small, medium, and large size classes, having as unit of measure the hectare (ha).

f) Distance between agricultural establishment and agribusiness (AgroDistance): measured by the distance of the rural property and agroindustry from sugar-alcohol. This logistical factor impacts on the analysis of potential costs and remunerations. The average distance in this search uses the unit of measure of kilometer $(\mathrm{km})$.

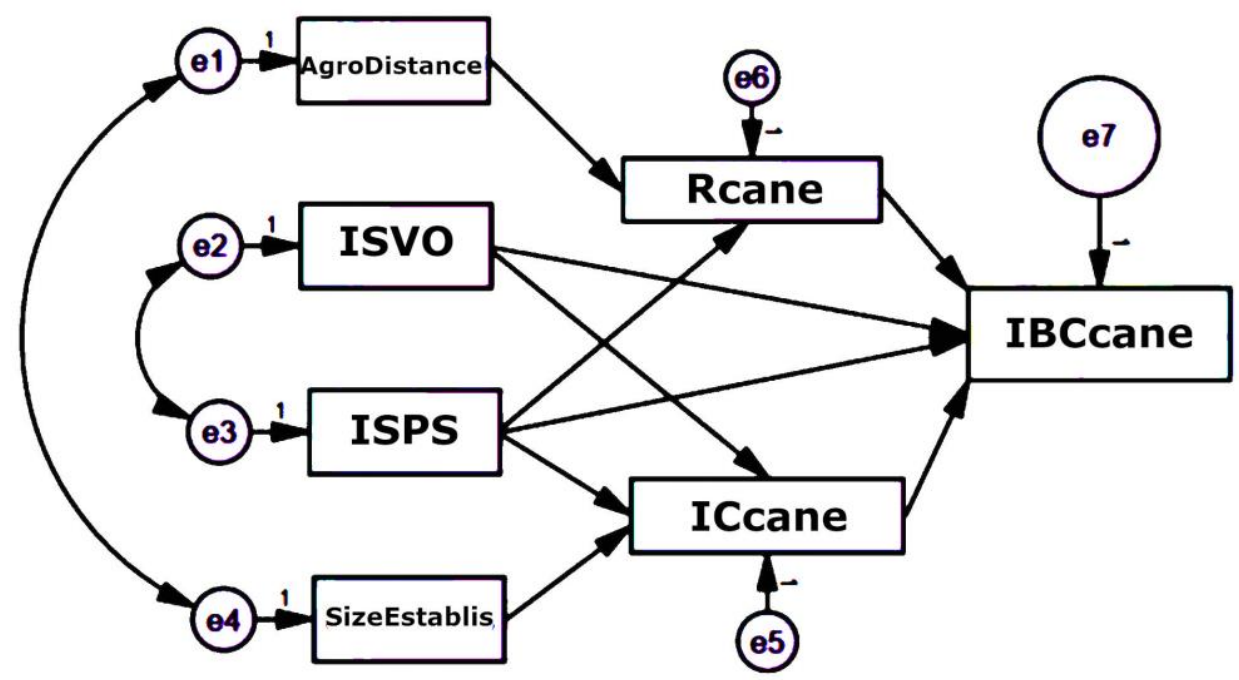

Figure 1. Theoretical model of the proposed basic hypothesis 


\subsection{Statistical Analyzes}

Statistical analysis began with the preparation and execution of the SEM (Structural Equation Modeling) analysis. Preliminary statistical tests were applied to the database: I) boxplot analysis to verify discrepancies, II) Kolmogorov-Smirnov and Shapiro-Wilk tests to support the assumption of normal data distribution, III) Friedman's ANOVA test, which verified that the null hypothesis $H_{0}$ was rejected, IV) multicolenicity test Variance Inflaction Factor, which verified the incidence of linearity among the variables, and V) Mann-Whitney test between group profiles.

The structural adjustment quality indicators SEM for the Path Analysis shall observe the following criteria: (a) the adjustment between the square xi $\left(\mathrm{X}^{2}\right)$ and the degree of freedom (df) shall be between 0 and $\leq 2$; b) For the Residual Mean Square Error of Approach (RMSEA) the verified value must be $<0.05$; c) For the Goodness of Fit Index (GFI) and Comparative fit index (CFI), the values must be between 0.95 to $\leq 1.00$; and d) Hoelter's Critical (0.05), the value must be $\geq 200$ (Abadi, 2019). The IBM $^{\circledR}$ SPSS Statistics, version 24.0 and Microsoft ${ }^{\circledR}$ Office Excel applications were used for the measurements and tests. The multivariate analysis in this article used the software IBM $^{\circledR}$ SPSS Amos, version 26.0 as a platform for estimation of correlations and path analysis.

\section{Results}

For the validation of the structural modeling of the equation, the satisfactory quality of the model adjustment at the $95 \%$ confidence level $(\mathrm{P}<0.05)$ was verified, by means of the following values: $\mathrm{X}^{2} / \mathrm{df}$ equal to 0.257 ; RMSEA equal to 0.000 ; CFI equal to 1.000 ; GFI equal to 0.987; and Hoelter (0.05) equals 406.

\subsection{The Results of Correlation and Path Analysis}

From the proposed path analysis, the data of the theoretical model were standardized (Figure 1), providing the scores regarding the relation between the independent variables and the dependent variable, obtaining an $\mathrm{R}^{2}$ of 0.74 , considering a significance of $\mathrm{P}$-value $<0.05$. After the application of the preparatory tests, the correlation test was verified, which demonstrated the relevance in the interrelationship between some variables.

Table 1. Correlations of the socioeconomic variables of the sugarcane production system

\begin{tabular}{lccccccc}
\hline \multicolumn{1}{c}{ Variables } & 1 & 2 & 3 & 4 & 5 & 6 & 7 \\
\hline 1 - ISVO & 1.000 & & & & & & \\
2 - ISPS & 0.856 & 1.000 & & & & & \\
3 - SizeEstablis & 0.04 & 0.04 & 1.000 & & & & \\
4 - AgroDistance & -0.051 & -0.001 & 0.546 & 1.000 & & & \\
5 - Iccane & 0.214 & 0.064 & 0.352 & 0.13 & 1.000 & & \\
6- Rcane & -0.141 & -0.156 & -0.182 & -0.404 & 0.003 & 1.000 & \\
7- IBCcane & -0.317 & -0.087 & -0.224 & -0.052 & -0.827 & 0.03 & 1.000 \\
\hline
\end{tabular}

The distance of the agroindustries from the rural establishment has a moderate and inversely proportional correlation with the income. The size of the rural establishment is moderately 
correlated with the cost of production index. The benefit/cost index presented a strong correlation with the cost of production index, but it is an inversely proportional influence.

It has been found that there is a strong correlation between the vocation and the practical ability of the successors. The other correlations tested showed a weak correlation. Aiming to deepen the characterization of the effects among the socioeconomic variables, the analysis in path (Table 1) was performed.

The total association between the cost of production index and the benefit/cost index was verified, showing a relationship with strong direct effect, despite expressing opposite meanings, and being statistically significant ( $>95 \%$ confidence). A disconnection between the remuneration with the production/lease of sugarcane and the benefit/cost ratio, with a weak direct convergent effect ( $<95 \%$ confidence). Likewise, there was no association between the distance from the rural establishment and the agroindustry with the benefit/cost index of the farms that have sugarcane productive activity, the analysis was mediated by the variable remuneration of the sugar cane activity, the tests showed a relationship with weak indirect effect, although significant (> 95\% confidence), according to Table 2.

Table 2. Association of direct, indirect and total effects among variables

Index Benefit/Cost by Cane (Dependent Variable)

\begin{tabular}{ccccc}
\hline $\begin{array}{c}\text { Independent } \\
\text { Variable }\end{array}$ & Direct Effects & Mediator & Indirect Effects & Total Effects \\
\hline ISVO & -0.46 & ICcane & -0.44 & $-0.90^{*}$ \\
ISPS & 0.36 & ICcane/Rcane & 0.34 & $0.70^{*}$ \\
SizeEstablis & 0 & ICcane & -0.26 & $-0.26^{*}$ \\
AgroDistance & 0 & Rcane & -0.01 & $-0.01^{*}$ \\
ICcane & -0.75 & - & 0 & $-0.75^{*}$ \\
Rcane & 0.02 & - & 0 & $0.02^{\mathrm{ns}}$ \\
\hline
\end{tabular}

Note 1. $*(\mathrm{P}<0,05) ;$ ns (not-significant);

Another relationship that verified disconnection was between the size of the agricultural establishment and the benefit/cost index of farms with productive activity of sugarcane, mediated by operating costs, had an indirect effect that was also weak convergent, although significant ( $>95 \%$ confidence). The total association between the successor's practical ability 
and the benefit/cost index that presented a substantial trail coefficient, in which the direct effect was convergent and relevant (51\%), with statistical significance. Relevant part of this association was indirect (49\%) and mediated by the composition of production costs, which was also associated with the receipt of remuneration with sugarcane activity (Table 2).

Likewise, there was a total association between the successor's vocation and the benefit/cost index that presented a substantial path coefficient, in which the direct and indirect effect was contrary and relevant (51\% and $49 \%)$, with statistical significance. The indirect association was mediated by the composition of production costs of sugarcane activity (Table 2).

\subsection{The Results of the Heterogeneity Test Among Rural Establishments}

The multicolenicity test Variance Inflation Factor found that the scores were lower than 3.6, a result not compatible with collinearity distortions, and the boxplot analysis did not identify outlines in the data. On the other hand, the normality tests applied the normal distribution, considering P-value significance $<0.05$, and Friedman's ANOVA test refuted the null hypothesis at the $95 \%$ confidence level (Table 3 ).

Table 3. Statistical and Mann-Whitney tests between group profiles

\begin{tabular}{|c|c|c|c|c|c|c|c|}
\hline & \multicolumn{2}{|c|}{ Normality Tests } & \multirow{2}{*}{$\begin{array}{c}\begin{array}{c}\text { Collinearity } \\
\text { test }\end{array} \\
\text { VIF }\end{array}$} & \multicolumn{4}{|c|}{ Mann-Whitney test } \\
\hline & $\begin{array}{c}\text { Kolmogorov } \\
\text {-Smirnov }\end{array}$ & $\begin{array}{l}\text { Shapiro } \\
\text {-Wilk }\end{array}$ & & $\begin{array}{c}\text { Producer } \\
\text { (Mean) }\end{array}$ & $\begin{array}{r}\text { Lessor } \\
(\text { Mean }) \\
\end{array}$ & $\begin{array}{c}\mathrm{U} \\
\text { Mann-Whitney }\end{array}$ & $P$-Value \\
\hline Rcane & 0.200 & 0.003 & 1.350 & 313.03 & 178.40 & 310.50 & 0.042 \\
\hline IBCcane & 0.000 & 0.000 & 1.410 & 1.67 & 9.81 & 41.50 & 0.000 \\
\hline ICcane & 0.003 & 0.000 & 3.480 & 60.03 & 10.19 & 35.50 & 0.000 \\
\hline ISVO & 0.000 & 0.000 & 3.544 & 3.19 & 1.76 & 255.50 & 0.017 \\
\hline ISPS & 0.000 & 0.000 & 2.986 & 3.14 & 2.43 & 361.00 & 0.642 \\
\hline SizeEstablis & 0.000 & 0.000 & 1.611 & 1002.29 & 348.92 & 251.00 & 0.026 \\
\hline AgroDistance & 0.004 & 0.000 & 1.857 & 23.74 & 22.38 & 359.50 & 0.638 \\
\hline
\end{tabular}

Note 2. The statistical tests considered a significance of $\mathrm{P}<0.05$.

The comparison between the lessors and suppliers to examine the heterogeneity of the farm intergroup variables, the final aspect of the objective of this study, was performed applying the Mann-Whitney test to verify after the index consolidation, the possible disparity. The results of the Mann-Whitney test measured values that show that there are variables that have a statistically significant difference between groups of lessors and suppliers (Table 3).

\section{Discussion}

The process of correlation and path analysis through the Structural Equation Modeling demonstrated a good fit quality of the proposed model through the adjustment indices presented through its scores. Based on the modeling results, $X^{2}$ (2.57) and df (10) representing the chi-square adjustment relationship with degree of freedom obtained a value 
of 0.257 , the RMSEA adjustment index obtained a score of 0 , indicating a perfect fit. In the estimation of the maximum structural likelihood of the model, the value of 0.987 for the GFI index was checked and the score was 1.00 for the CFI index. All the results indicate a very good fit for the proposed model (Abadi, 2019). The Hoelter criterion (0.05) is one of the adequacy measures developed to test if the sample size is adequate, the result of this quality indicator was 406, allowing to infer that the sample was adequate, since it meets the criteria of Quality (Garson, 2009).

The coefficients of determination $\left(\mathrm{R}^{2}\right)$ represent the percentage of variation in the composition of the benefit/cost index, which was explained by the socioeconomic variables of the sugarcane production system relative to rural establishments: total operating cost, compensation, size of rural establishment, distance from the establishment and agroindustry, vocation and practical ability of the successor. Overall, the value of $\mathrm{R}^{2}$ was relatively high, which indicated that the variables accounted for almost the entire variation of the IBCcane (Abadi, 2019; Qaswar et. al., 2019).

Benefit-cost index control is usually applied as a tool for decision-making in the choice of risk reduction strategies that credit importance to the costs of the measures and the outcome to be achieved (Špačková and Straub, 2015). The model of the analysis of the relationships between the proposed socioeconomic variables was configured with the benefit/cost index, being composed of two groups of variables: compensation and costs. Statistical analyzes showed that the impact of the remuneration component was statistically insignificant. On the other hand, the variables related to costs showed a strong correlation and a substantial direct effect on IBCcane.

It was latent that the costs are the main vector of impact on the result of the productive activities of the sugarcane, but it is emphasized that its vector is inverse, that is, when one variable increases its value the other decreases. Thus, costs have a direct reduction effect on the benefit/cost index in the sugarcane production system, emphasizing the importance of the management of the productive process to control the cost dimensioning (Nacife et al., 2019), in which the scale of production factor is a distinguishing factor among rural establishments, since those with greater territorial extension also have a greater capacity to prorate production costs (Strelecek et al., 2011; Pokharel and Featherstone, 2019).

The role of the successor in rural establishments has been important before and after assuming the functions of directing the activities, influencing the paths regarding the prospects of their development (Wheeler et al., 2012). The present study verified the existence of a strong correlation between the social factors of vocation and the practical ability of successors inserted in productive activities of sugarcane (Table 1 and 2). Both factors have shown a direct and indirect impact on the economic results of rural establishments with significant and significant effects.

For the success of agriculture today, it has been required training and participation of successors in agricultural activities and their management (Burton and Fischer, 2015). The social variables related to the vocation and practical ability of the successors showed a prominent observed correlation between them, which also allows to infer that the 
involvement of the successors with responsibility in the activities of the rural establishment, impacts directly or indirectly on the results of IBCcane (Inwood and Sharp, 2012). In addition, that revenue from sugarcane activity depends on arrangements and combinations of markets, but that social factors can be directly associated with the levels of productivity and profitability of establishments in this agricultural sector (Dubb, 2017).

The Mann-Whitney (Conformity Test) between the profiles of rural lessor groups and sugarcane suppliers for the sugar and alcohol agroindustries showed that there were statistically significant differences between lessors and suppliers. The remuneration obtained had the value provided by the suppliers statistically higher than the value of the lessors, considering a level of $5 \%$ of significance. The benefit/cost ratio had a statistically lower value for suppliers than the lessors' index (> 95\% confidence).

However, the total operating cost had its value from suppliers statistically higher than the index presented by lessors ( $>95 \%$ confidence). The size variable of agricultural establishments obtained a value from suppliers that was statistically higher than the index presented by the lessors and the succession index relative to succession, had their value of suppliers statistically also higher than the index presented by lessors (>95\% confidence). For the other variables, there were no statistically significant differences between lessors and suppliers.

It was found that $\pm 70 \%$ of the socioeconomic variables studied among the groups of rural establishments are heterogeneous, adhering with the findings of Dubb (2017), who reports that the forms of relations between sugarcane producers and agroindustries are dynamic, regardless of their type of contract, but this study shows specifically which social factors influence directly or indirectly the indicator of benefit/cost of sugarcane activities for rural producers.

\section{Conclusion}

In the dynamics of the socioeconomic factors of the sugarcane productive system, the influence of social variables on the economic result is expressive, and the indirect effects impact in a manner similar to the direct ones, as evidenced by the analysis of the benefit/cost. The costs have a strong impact on the economic result, with direct effect on the benefit/cost index of the sugarcane activity. This study contributes to the adoption of actions that prepare the successors for agricultural management and agribusiness management. The management of different types of contracts for the supply of sugarcane agroindustries require different strategies for lessors and suppliers due to the mostly heterogeneous peculiarities of their variables.

\section{Acknowledgement}

This research was supported by the Goiás Sugarcane Suppliers Association (APROCANA Associação dos Fornecedores de Cana Goiás), Departments of Agriculture and Environment, Industry and Commerce and Tourism of the Quirinópolis City Hall, Faculdade Quirinópolis and led by the Graduate Program in Agricultural Sciences of the Goiano Federal Institute (IF GOIANO - Instituto Federal Goiano), Campus Rio Verde. We especially thank the institutional support of the Goiano Federal Institute (IF GOIANO), Campus Rio Verde. The opinions expressed in this article do not necessarily reflect the opinions of our supporters or partners. 


\section{References}

Abadi, B. (2019). How agriculture contributes to reviving the endangered ecosystem of Lake Urmia? The case of agricultural systems in northwestern Iran. Journal of Environmental Management, 236, 54-67. https://doi.org/10.1016/j.jenvman.2019.01.111

Barnes, A. P., Hansson, H., Manevska-Tasevska, G., Shrestha, S. S., \& Thomson, S. G. (2015). The Influence of Diversification on long-term Viability of the Agricultural Sector. Land Use Policy, [S.1], 49, 404-412. https://doi.org/10.1016/j.landusepol.2015.08.023

Bellino, A., Baldantoni, D., De Nicola, F., Iovieno, P., Zaccardelli, M., \& Alfani, A. (2015). Compost amendments in agricultural ecosystems: Confirmatory path analysis to clarify the effects on soil chemical and biological properties. Journal of Agricultural Science, 153(2), 282-295. https://doi.org/10.1017/S0021859614000033

Burton, R. J. F., \& Fischer, H. (2015). European Society for Rural Sociology. Sociologia Ruralis, 55(2),155-166. https://doi.org/10.1111/soru.12080

CONSECANA, Conselho dos Produtores de Cana de Açúcar, Açúcar e Etanol do Estado de São Paulo. (2018). Database. Available at https://www.consecana.com.br/login.asp?url=preco_mensal.asp. (Accessed August 2018)

Dubb, A. (2017). Questioning the Logic of Sugar Sector Accumulation in Southern Africa, Journal of Southern African Studies, 43(3), 471-499.

https://doi.org/10.1080/03057070.2016.1219153

FAO - Food and Agriculture Organization of the United Nations. (2016). Economic Analysis of Animal Diseases. Available at http://www.fao.org/3/a-i5512e.pdf. (Accessed August 2018)

Garson, G. D. (2009). Computerized Simulation in the Social Sciences: A Survey and Evaluation. Simulation \& Gaming, 40(2), 267-279.

https://doi.org/10.1177/1046878108322225

IBGE-Instituto Brasileiro de Geografia e Estatística. (2018a). Agricultural Census-Preliminary results, 2017. Available at https://sidra.ibge.gov.br/ (Accessed September 2018)

IBGE-Instituto Brasileiro de Geografia e Estatística. (2018b). Cities. Available at http://cidades. ibge.gov.br/xtras/home.php (Accessed January 2019)

Inwood, S. M., \& Sharp, J. S. (2012). Farm persistence and adaptation at the rural-urban interface: Succession and farm adjustment. Journal of Rural Studies, 28(1), 107-117.

https://doi.org/10.1016/j.jrurstud.2011.07.005

Nacife, J. M., Soares, F. A. L., \& Castoldi, G. (2019). Socioeconomic Characteristics and the Impacts of Land Use Changes to Sugar Cane in Quirinópolis, Brazil. Journal of Agricultural Science, 11(10), 180-193. https://doi.org/10.5539/jas.v11n10p180

Pokharel, K. P., \& Featherstone, A. M. (2019). Estimating multiproduct and product-specific 
scale economies for agricultural cooperatives. Agricultural Economics, 50, 279-289. https://doi.org/10.1111/agec.12483

Qaswar, M., Ahmed, W., Jing, H., Hongzhu, F., Xiaojun, S., Xianjun, J., \& Zhang, H. (2019). Stoichiometry of soil carbon (C), nitrogen (N) and phosphorus (P) induces phosphorus lability in paddy soil under long-term fertilization: A fractionation study and path analysis. PLoS ONE, 14(6), 1-20. https://doi.org/10.1371/journal.pone.0218195

Santos, D. F. L., Mendes, C.C., Farinelli, J. B. de M., \& Farinelli, R. (2016). Viabilidade econômica e financeira na produção de cana-de-açúcar em pequenas propriedades rurais. Custos e Agronegocio, 12(4), 222-254.

Santos, G.E.O. (2016). Sample calculation: online calculator. Available at http://www.calculoamostral.vai.la. (Accessed June 2018)

Špačková, O., \& Straub, D. (2015). Cost-Benefit Analysis for Optimization of Risk Protection Under Budget Constraints. Risk Analysis, 35, 941-959.

https://doi.org/10.1111/risa.12310

Spera, S., VanWey, L., \& Mustard, J. (2017). The drivers of sugarcane expansion in Goiás, Brazil. Land Use Policy, 66, 111-119. https://doi.org/10.1016/j.landusepol.2017.03.037

Strelecek, F., Zdenek, R., \& Lososová, J. (2011). Influence of the production change on the return to scale. Agricultural Economics, Czech, 57(4), 159-168.

https://doi.org/10.17221/93/2010-AGRICECON

Wheeler, S., Bjornlund, H., Zuo, A., \& Edwards, J. (2012). Handing down the farm? The increasing uncertainty of irrigated farm succession in Australia. Journal of Rural Studies. 28(3), 266-275. https://doi.org/10.1016/j.jrurstud.2012.04.001

\section{Copyright Disclaimer}

Copyright for this article is retained by the author(s), with first publication rights granted to the journal.

This is an open-access article distributed under the terms and conditions of the Creative Commons Attribution license (http://creativecommons.org/licenses/by/4.0/). 